\title{
Mapping the Social Organization of Labour in Moscow: Beyond the Formal/informal Labour Dualism
}

\author{
by Colin C. Williams, Sara Nadin, Peter Rodgers, John Round and Jan Windebank \\ University of Sheffield
}

Sociological Research Online, 16 (1) 13

$<h t t p: / / w w w . s o c r e s o n l i n e . o r g . u k / 16 / 1 / 13 . h t m l>$

$10.5153 /$ sro.2244

Received: 25 May 2010 Accepted:21 Jan 2011 Published: 28 Feb 2011

\begin{abstract}
The starting point of this paper is recognition that the depiction of a formal/informal labour dualism, which views formal and informal labour as separate and hostile realms, is inappropriate for capturing the range of labour practices in societies. This is because labour practices cannot be neatly separated into discrete formal and informal realms, the differences within the formal and informal spheres are as great as the differences between the two realms, and formal and informal labour are not always embedded in different economic relations, values and motives. Here, an alternative more nuanced conceptual lens is proposed that resolves these problems and in so doing captures the multifarious labour practices in societies, namely the total social organization of labour (TSOL) perspective. This depicts labour practices as existing along a spectrum from more formal-oriented to more informal-oriented practices and cross-cuts this with a further spectrum from non-monetized, through in-kind and reciprocal labour, to monetized labour. Applying this conceptual lens, the results of a survey of the anatomy of labour practices in an affluent, mixed and deprived district of Moscow, comprising 313 face-to-face interviews, are then analysed. This reveals that socio-spatial variations in the organisation of labour are not solely about the degree of formalization of working life. Instead, this study unravels that populations range from relatively affluent 'work busy' populations undertaking, and voluntarily selecting from, a multiplicity of labour practices, to relatively disadvantaged 'work deprived' populations engaged in a narrower range of practices and more commonly disadvantaged 'work deprived' populations engaged in a narrower range of practices and more commonly out of necessity and in the absence of alternatives. The outcome is call for both the wider application and
refinement of this TSOL approach when mapping the social organisation of labour and evaluations of whether the findings from Moscow are more widely valid in other societal contexts.

\section{Keywords: Informal Sector; Labour Practices; Livelihoods; Household Work Practices; Economic Sociology; Uneven Development; Eastern Europe; Russia; Moscow}

\section{Introduction}

1.1 For many decades, it was common to view any labour practice as either formal or informal, with each composed of different economic relations, values and motives (Geertz, 1963; Lewis, 1959). However, an emerging caucus of literature has begun to question the validity of using a formal/informal labour dualism when representing the range of labour practices in societies. This is because it is becoming increasingly recognised that, firstly, labour practices cannot be neatly separated into being either formal or informal practices, secondly, the differences within each sphere are as great as the differences between the two realms and third and finally, formal and informal labour are not always composed of different economic relations, values and motives (Gibson-Graham, 2006, 2008; Glucksmann, 2005; Taylor, 2004; Williams, 2005, 2009; Williams and Zelizer, 2005). The out 2005, 2009; Williams and Zelizer, 2005). The outcome has been a growing call to transcend the depiction of labour as either formal or informal. Until now, however, few alternative ways of ordering the multifarious labour practices in societies have emerged which might replace this formal/informal labour dualism. One of the only exceptions is the 'total social organization of labour' (TSOL) approach proposed by Glucksmann (2005). In this paper, therefore, the aim is to understand the organization of labour in post-socialist Moscow using this concept of the TSOL and in so doing to display how it represents a solution to the problem of analyzing the diversity of labour practices.

1.2 To achieve this, the first section will review the limited understandings of labour practices that have resulted from using a formal/informal labour dichotomy and having noted the lack of alternatives currently available, the TSOL approach of Glucksmann (2005) will be introduced. The outcome will be the presentation of a conceptualisation of labour practices that transcends the simplistic formal/informal labour dichotomy by representing labour practices in societies as existing along a spectrum from relatively formaloriented to more informal-oriented practices cross-cut by a further spectrum from non-monetized, through gift-giving and in-kind reciprocal labour, to monetized labour. In the second section, this framing will be then applied to understand the diverse labour practices in Moscow and to map the socio-spatial variations in work cultures and individual labour practices in this global city that is undergoing a transition to postsocialism. Analyzing the results of 313 face-to-face household interviews, this will uncover the shallow permeation of formalization and the wide array of labour practices currently used along with how both work cultures as well as individual labour practices differ across deprived, mixed and affluent districts in this post-Soviet city. This will reveal that uneven development in Moscow is characterized by relatively affluent populations who are more 'work busy' undertaking, and voluntarily selecting from, a multiplicity of labour practices, and relatively disadvantaged 'work deprived' populations engaged in a narrower range of practices and more commonly out of necessity and in the absence of alternatives. The final section will practices and more commofl then call for a re-reading of the organization of labour in Moscow along with the wider application of this
lens a tor mapping the multiplicity of labour practices in societies.

\section{Mapping labour practices: beyond the formal/informal economy dualism}

2.1 During the twentieth century, a dominant discourse was that goods and services were being increasingly produced and delivered in the formal economy and that the informal economy was gradually disappearing due to the natural, inevitable and irrefutable formalization of work. The informal economy was consequently often depicted as a residue from an earlier mode of production and a sign of 'underdevelopment', 'traditionalism' and 'backwardness', while the formal economy signalled 'progress', 'development', 'modernity' and 'advancement' (Boeke, 1942; Geertz, 1963; Lewis, 1959). Such a classic representation of the formal and informal economies as separate spheres, unified realms and hostile worlds has been variously referred to as the 'modernization', 'dual economy', 'residue' or 'formalization' theses 
2.2 This dualistic depiction that viewed the formal economy as strong, extensive and growing, and the separate and hostile informal economy as weak, marginal and declining, reflects what Derrida (1967) calls a hierarchical binary way of thinking. Firstly, it conceptualizes two opposing economies which are stable, bounded and constituted via negation and secondly, reads these resultant separate economies hierarchically bestowing the superordinate (the formal economy) with positive attributes and as growing, whilst the bersing whilst the subordinate or subservient 'other' (the informal economy) is endowed with negativity and as dwindling. The outcome has been to establish a relationship of opposition and exclusion, rather than
similarity and mixture, between the two realms and to imbue the resultant dichotomy with a normative and temporal narrative of 'progress' in which the extensive superordinate 'us' (the formal economy) was privileged over the separate, much weaker and residual subordinate 'other' (the informal economy).

2.3 Indeed, this classic perspective that represented the informal and formal as separate and discrete continues to hold sway. In some quarters, there remains a belief that the formal and informal economies are separate both in temporal and normative terms as well as in terms of the workers, business, spaces and populations involved. Firstly, that is, the temporally discrete depiction of the formal and informal which portrays the informal economy as the 'old' mode of production and the formal economy as 'new' (Boeke, 1942; Geertz, 1963; Lewis, 1954) has proven remarkably resilient to change. Indeed, its continuing usage can be clearly seen in the adoption of labels such as 'pre-modern' (Rose, 2005: 26) and 'primitive domestic economy' (Burawoy and Verdery, 1999) to portray informal labour. The outcome is that informal labour continues to be read as a leftover or 'mere vestige of a disappearing past [or as] transitory or provisional' (Latouche, 1993: 49) and represented as traditional, stagnant, marginal, residual, weak, and about to be extinguished, whilst formal labour is read as strong, growing and extensive.

2.4 Secondly, formal and informal labour continues to be read as normatively discrete, with informal labour portrayed as regressive and a sign of 'under-development', 'traditionalism' and 'backwardness' (Geertz, 1963) whilst formal labour is seen as a sign of 'progress', 'development', 'modernity' and 'advancement' (Lewis, 1954), as displayed by the ILO (2002) when it calls for the eradication of informal labour and a shift towards so-called 'decent work' in the formal economy.

2.5 Formal and informal labour continues to be depicted not only as temporally and normatively discrete but also as belonging to separate spaces at a range of geographical levels from the intra-urban to the global scale. At the intra-urban level, this spatial separateness finds expression in the marginality thesis that consigns informal labour in advanced economies to deprived neighbourhoods (Elkin and McLaren, 1991) and in third world cities to shanty towns (Davis, 2006). At the scale of global regions, meanwhile, informal labour is often similarly depicted as occupying poorer regions, as seen in the European Union where it is sometimes assumed to be concentrated in southern European states (European Commission, 1998) whilst at the global level, countries are again ordered into a hierarchical queue with advanced economies, viewed as near fully formalised, at the front with other nations behind them ordered according to their degree of apparent formalisation (Massey, 2005). The outcome is a depiction of informal and formal labour as occupying discrete spaces with formal spaces extensive and informal spaces being scattered and fragmented in the outer margins of the economic landscape.

2.6 Fourthly, a similar marginality thesis persists when discussing whether formal and informal labour belongs to separate populations and businesses. A strong and resilient view has been that the individuals and businesses engaged in informality are those marginalised from the formal economy (e.g. Castells and Portes, 1989; De Soto, 1989; ILO, 2002), meaning that one set of individuals and businesses engage in the formal economy and another ('othered') set of individuals and firms in the informal economy (e.g., Tokman 1989), each with their own internal logics (Fernandez-Kelly, 2006).

2.7 For well over a decade, however, this classic dualistic representation of formal and informal labour as being temporally and normatively discrete and also as being conducted by separate workers, businesses, spaces and populations, has started to be challenged. Firstly, their temporal separateness has been questioned by an extensive literature which reveals how formal and informal labour co-exist in the present and rise and fall in tandem (Charmes, 2009; Feige and Urban, 2008; ILO, 2002; Jütting and Laiglesia, and rise and fall in tandem (Charmes, 2009; Feige and Urban, 2008; ILO, 2002; Jütting and Laiglesia,
(20) not always either informal or formal. Instead, individual workers, individual enterprises and particular populations have been shown to often engage in both formal and informal labour (Lee, 2006; Smith and Stenning, 2006; Williams, 2006; Williams and Round, 2007b). Moreover, to see how labour is not always either formal or informal, and how economic relations, values and motives do not always markedly differ, one needs look no further than the fact that one in 20 formal employees in the European Union receive from their formal employer not only a declared wage but also an additional undeclared wage, displaying how informal and formal labour are sometimes inseparable from each other in contemporary capitalism (Williams, 2009; Woolfson, 2007). To see that the differences within each sphere are as great as the differences between them, meanwhile, one needs only note how not all formal labour is progressive (e.g., zero-hours contracts, false self-employment) and neither is informal labour necessarily always regressive (e.g., mutual aid, community self-help, volunteering).

2.8 The outcome is that the normative separateness of formal and informal labour has started to be challenged (Gibson-Graham, 2006; Lee, 2006; Samers, 2005; Smith and Stenning, 2006; Williams and Round, 2007). Although at first the hierarchical binary that depicted formal labour as 'progressive' and Round, 2007). Although at first the hierarchical binary that depicted formal labour as 'progressive' and
informal labour as 'regressive' was simply inverted by arguing that informal labour was 'progressive' and formal labour often 'regressive' (De Soto, 2001), recent years have witnessed the advent of more nuanced arguments. A diverse range of critical, post-colonial, post-development, post-structuralist and postcapitalist theorists (e.g., Chakrabarty, 2000; Community Economies Collective, 2001; Escobar, 1995; Gibson-Graham, 1996, 2006; Lee, 2006; Leyshon et al, 2003; Williams and Round, 2007) have instead blurred the boundaries between the two. Following either Butler (1990) by highlighting the performativity of this normative separateness and/or the path laid by Derrida (1967) and Foucault (1977) of discourse this normative separateness and/or the path laid by Derrida (1967) and Foucault (1977) of discourse analysis and deconstruction, these commentators have sought not so much to invert the normative
hierarchy but, rather, to highlight the similarities on both sides and to show how the formal and informal are not always composed of entirely different economic relations, values and motives (Chowdhury, 2007; Escobar, 2001; Gibson-Graham, 2006; Gupta, 1998; Lee, 2006;Pollard et al, 2009; Smith and Stenning, 2006; Williams, 2005; Williams and Zelizer, 2005).

2.9 In consequence, there is now gathering pace a loose body of knowledge that is challenging the longstanding depiction of formal and informal labour as separate and unified spheres as well as hostile worlds. The most common classificatory schema used in practice to demonstrate the need to recognise the differences and similarities on each side has been to retain a broad distinction between formal and informal differences and similarities on each side has been to retain a broad distinction between formal and in
labour but to show how the informal side is not unified by breaking it down into three very different practices, namely: self-provisioning, which is where a household member engages in unpaid work for themselves or another member of their household; unpaid community labour where a household member engages in unpaid work for somebody who lives outside of the household, and paid informal labour where paid work is conducted that is unregistered by, or hidden from, the state for tax, social security and/or labour law purposes (Leonard, 1998; Pahl, 1984; Slack, 2007; Slack and Jensen, 2010; Smith, 2010; Smith and Stenning, 2006; Wallace and Latcheva, 2006: Williams, 2005, 2010). The problem is that although this classification of labour practices unpacks some of the diversity in informal practices, it leaves intact formal labour as a unified whole and also the notion that the formal and informal are separate spheres composed of distinct economic relations, values and motives.

2.10 This is similarly the case with other conceptual frameworks. Gibson-Graham (2006), for example, differentiate transactions into three sub-categories, namely market, alternative market (e.g., off-the-books, barter) and non-market (e.g., gift-giving, subsistence), and also labour practices again into three broad types, namely waged, alternative paid (e.g., cash-in-hand, reciprocal) and unpaid (e.g., family care, selftypes, namely waged, alternative paid (e.g., cash-in-hand, reciprocal) and unpaid (e.g., family care, self-
provisioning). Although these again unpack the informal labour side of the coin, they leave the formal side intact as a unified whole and continue to portray formal and informal as separate distinct spheres. 
2.11 How, therefore, can the multiple kinds of labour that exist in economies be portrayed more in a manner that shows how the formal and informal are not separate, that the differences within formal and informal-oriented activities are as great as the variations between them, and that the economic relations, values and motives of formally-oriented and informally-oriented activities are not always different and hostile? Perhaps the most prominent and promising attempt so far made is the total social organization of labour' (TSOL) approach of Glucksmann (2005: 28) who reads the economy as a "multiplex" combination of modes, rather than as a dualism...'. In this approach, and as Taylor (2004) shows, a continuum of labour practices according to their degree of formality is constructed and this continuum is then cross-cut by practices according to their degree of formality is constructed and this continuum is then cross-cut by
whether the labour is paid or unpaid (Glucksmann, 1995, 2005). This concept of the TSOL was originally used to elucidate the gendered connections between paid and unpaid work and has been widely applied (Acker, 2006; Bradley, 2007; Crompton, 2006; Glucksmann, 2000, 2009; McDowell, 2005; Pettinger et al, 2005; Strangleman and Warren, 2008). Much of the work has so far drawn attention to the 'multi-modal' character of contemporary capitalism and how terms like the 'dual economy' and the 'mixed economy' barely capture the complexity and variety of forms of provision in existence. This concept, moreover, has been argued to be applicable at micro, meso or macro levels and to units at a range of scales, from the individual and household to a country or global region. One attempt to display this is the work conducted by Lyon and Glucksmann (2008) which compares the contribution of different modes of provision to elder care work in four countries (Italy, the Netherlands, Sweden and the UK), revealing how various forms of provision not only have different roles and significance in each country but also interact in nationally distinctive ways.

2.12 In this paper, the intention is to apply this concept of a TSOL to understanding not how forms of provision vary across countries but across locality-types in a particular global city, namely Moscow in Russia. To map this, and as Figure 1 displays, a seamless range of labour practices is constructed ranging firstly along a spectrum from relatively formal to more informal labour practices and secondly, and crosscutting this, along a further spectrum (rather than dualism) from wholly non-monetized, through gift exchange and in-kind labour, to wholly monetized labour practices. Hatched circles are deliberately used to display how although various labour practices along these continua can be named, they are in effect part of a borderless continua of practices, rather than separate kinds of labour, which overlap and seamlessly merge into one another as one moves along both the formal/informal spectrum of the $x$-axis as well as along the monetisation/non-monetisation spectrum of the $y$-axis. Here, therefore, and unlike previous frameworks, the borderless fluidity between different labour practices is captured and it is clearly shown how the multiple practices are not discrete but seamlessly entwined and conjoined.

\section{Paid}

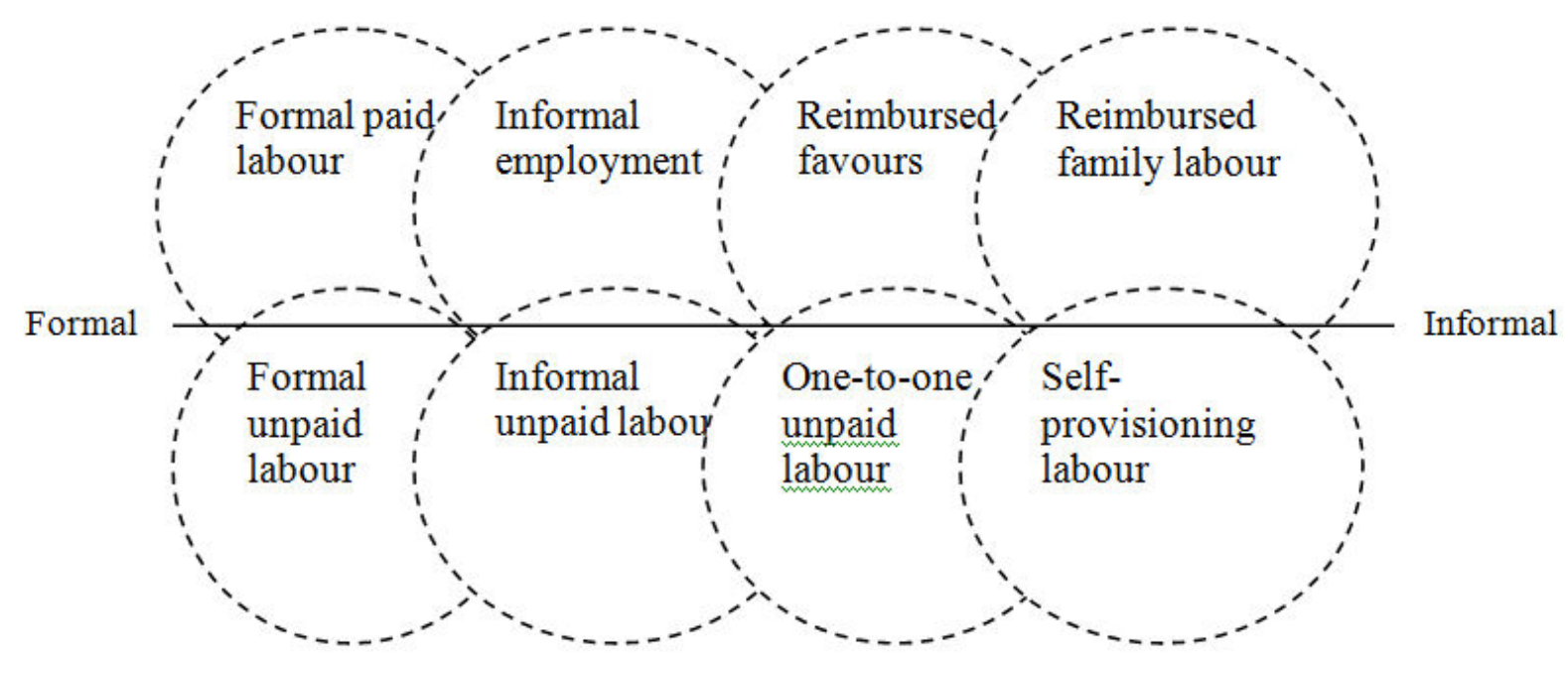

\section{Unpaid}

Figure 1. A typology of labour practices

2.13 The outcome is that eight broad overlapping labour practices can be identified, each of which possess within them different varieties of labour and which merge at their borders with the other practices. Firstly, there is formal paid labour, defined as paid work registered by the state for tax, social security and labour law purposes. Within this formal sphere, three types of formal labour, namely in the private, public and third sectors have been conventionally distinguished. However, given that private sector organizations are increasingly pursuing a triple bottom line, whilst public and third sector organizations are also pursuing profit (albeit in order to reinvest so as to achieve wider social and environmental objectives), an ongoing blurring of the boundaries these three formal spheres is occurring. Formal paid labour as a whole, moreover, is not discrete and separate since it often merges with both formal unpaid labour and informal employment.

2.14 Informal employment is here defined as paid labour unregistered by or hidden from, the state for tax, social security and labour law purposes (Williams, 2009). Different varieties again exist, ranging from wholly undeclared labour where none of the payment is declared for tax, social, security and labour law purposes, to under-declared formal employment where formal employees receive an additional undeclared wage from their formal employer alongside their formal declared wage or the formal self-employed do not declare various portions of their earnings (Williams, 2009). Conventionally, however, and adopting a formal/informal economy depiction of separate and hostile spheres, a job or labour contract was assumed to be either formal or informal but not both. Nevertheless, under-declared formal employment clearly shows how labour can be concomitantly both formal and informal, meaning that the formal/informal divide is more blurred than previously considered in dualistic representations.

2.15 Formal employment not only overlaps with informal employment but also formal unpaid labour. Again, various types exist. In the private and public sectors, formal unpaid labour can take the form of unpaid internships or one-week trials, and people do this expecting paid employment at the end. Sometimes, however, businesses fail to pay their formal employees for protracted periods (Shevchenko, 2009), so it is not conducted as a matter of choice. It is in third sector organizations, nevertheless, that such labour is most extensive, and commonly termed 'formal volunteering', which refers to 'giving help through groups, clubs or organizations to benefit other people or the environment' (Low et al, 2008: 11). In some instances, this can become 'off-the-radar' unpaid labour, when help is again provided through groups to benefit other people or the environment but the required formalities required by law have not all been fulfilled, such as when a children's football coach volunteers but without have undertaken the required police checks. 
2.16 One-to-one unpaid labour refers to labour provided on an individualized level to members of households other than one's own such as kin living outside one's household, friends, neighbours and acquaintances. This again is of different kinds ranging from individualized one-way giving (often termed 'informal volunteering') to two-way reciprocity. When reciprocity is involved, such unpaid endeavour often blurs into reimbursed favours since the reciprocity may take the form of either in-kind labour or gifts in lieu of payment. Indeed, whether one-to-one labour when reimbursed in-kind or with gifts (as well as when paid) is closer to informal employment or to paid favours depends on the economic relations, values and motives involved. Financial gain is usually more prominent when more distant social relations are involved, and redistributive and relationship-building purposes more prominent when conducted for and by closer social relations, thus displaying how informal employment and reimbursed favours represent a continuum of, rather than separate, labour practices.
of

2.17 Turning to labour practices within the family household, most is self-provisioning which is defined as unpaid work conducted by household members for themselves or for other members of their household. Sometimes, nevertheless, family members are reimbursed for tasks conducted for and by other household members using either money, gifts or in-kind reciprocal labour. Monetary payment is nearly always reserved for inter- rather than intra-generational exchanges (e.g., from a parent to a child). When gifts and in-kind reciprocal labour are included, however, the divide between monetized and non-monetized labour becomes blurred. Indeed, it is perhaps rare in couple households that domestic tasks are today conducted wholly unpaid with no expectation of future reciprocity. Even unpaid housework, an activity often viewed as wholly non-monetized and non-exchanged, is often embedded in expectations of reciprocity in couple households. Moreover, what constitutes family and non-family is by no means always clear cut, and therefore differentiating family work (self-provisioning) from one-to-one community exchanges is sometimes difficult, since current acquaintances, friends and even neighbours might well be past or future family.

2.18 In what now follows, this TSOL concept which depicts a seamless spectrum from formal to informal orientated practices, cross-cut by a continuum from reimbursed to non-reimbursed practices, is now applied to understanding the organization of labour in Moscow.

\section{Examining labour practices in Moscow}

3.1 To what extent has the formal economy permeated the daily life of Muscovites? Do other labour practices persist and if so, which kinds? And do the work cultures of Muscovites and the nature of individual labour practices vary socio-spatially? To answer these questions, the TSOL framework is here used to analyse evidence collected in 2005 and 2006 during 313 face-to-face interviews in Moscow, a global city of some 10.4 million inhabitants (Brooke, 2006) where previous surveys reveal not only some marked cultural differences to the rest of Russia but also a long legacy of the use of work beyond formal employment (Brooke, 2006; Clarke, 2002; Caldwell, 2004; Ledeneva, 2006; Shevchenko, 2009). This is also a global city that remains in transition to post-socialism with the transformation being far from complete (Shevchenko, 2009). As such, it is necessary to recognise that the forms of work organization that prevail in different districts of Moscow are likely to be far from a steady-state.

3.2 As Clarke (2002) reveals in relation to Russia, moreover, during the Soviet period there were numerous services that no state enterprise provided and which were wholly delivered privately by individuals off-thebooks, such as small construction and decorating jobs, repair of radios, televisions and washing machines, clothing repairs, care for the elderly and sick, private transport and private tuition. Indeed, until 1987, doing these odd jobs for pecuniary reward was illegal per se despite citizens having no other way of obtaining such services. The outcome was a heavy reliance on informality in the so-called 'second economy' (Ledeneva 1998). Informal employment in the contemporary era, in consequence, has a different historical legacy for the population of Moscow in particular, and the ex-Soviet bloc more generally, compared with western economies and much of the third world.

3.3 Furthermore, it is important to understand the context in which household employment decisions are made, especially Russian labour market legislation and the tax and benefits regimes. Superficially, taxation is extremely straightforward, with a uniform rate of 13 per cent on personal income and a corporation tax level of 20 per cent. In practice, however, it is more complex. As Round et al. (2008) outline, many formal employees receive two wages from their formal employer, one formal and the other in cash at the end of the month. This allows employers to evade payroll taxes, and state pension contributions, and makes wage payments very uncertain for employees as they have no guarantee that their unofficial wage will be paid. If it is not, they have no recompense because if they complain to the state, they will be open to accusations of tax evasion on previously paid informal payments. Labour legislation is also extremely problematic in Russia. Although a myriad of labour regulations exist to protect workers, few are adhered to in practice (see Round et al., 2008). As Clarke (2002) displays, many people rely on contact networks to obtain employment, as opposed to applying for posts in open competition, and in some instances bribes are required to obtain employment (Round et al. 2008). In sum, great care is needed not to extrapolate the findings from this survey to either Russia more generally, post-socialist societies or other regions of the findings from this survey to either Russia more generally, post-socialist societies or other regions of the
world. Instead, the intention here is solely to use this study of Moscow to begin to highlight how the TSOL varies across locality-types within this global city so as to draw attention to the intra-urban variations in the TSOL which can then be tested to see if they are also valid elsewhere.

3.4 Newcomers to the study of such labour practices might assume that researching this topic in Moscow is difficult due to the hidden nature of some of these forms of labour. Previous studies undertaken in other countries, however, clearly display that even if this endeavour is hidden from the state for tax and social security purposes, this does not mean that people will not openly discuss such practices academic security purposes, this does not mean that people will not openly discuss such
researchers (Leonard 1994; MacDonald 1994; Pahl 1984; Williams 2004, 2006).

3.5 Given that previous studies in Moscow (Pavlovskaya, 2004; Shevchenko, 2009), Russia (Clarke, 2002; Kim, 2002), East-Central Europe (Wallace and Haerpfer, 2002; Wallace and Latcheva, 2006; Williams, 2005) and western nations (Leonard, 1998; Renooy, 1990; Williams, 2010) identify significant variations in participation in formal and informal labour across affluent and deprived populations, the decision was taken to use maximum variation sampling to select three contrasting districts of Moscow to survey. Firstly, an affluent oblast in the west of Moscow, namely Krylatskoe, was chosen, secondly, one of the most deprived oblast located in the South-East of Moscow and third and finally, a mixed oblast to the west of the Moscow region, about $25 \mathrm{~km}$ out from the Moscow ring road (which is the Moscow city border), namely Leshkovo, where 'new Russians' live in large expensive houses alongside benefit-dependent pensioners and the 'working poor'.

3.6 In each oblast, a spatially stratified sampling methodology was used to select households for interview (Kitchin and Tate, 2001). If there were some 1,000 households in the oblast and 100 interviews were sought, that is, the researcher called at every $10^{\text {th }}$ household. If there was no response and/or an interview was refused, then the 11th household was visited, then the 9th, 12th, 8th and so on. This provided a spatially stratified sample of each oblast. In total, 313 face-to-face interviews were conducted in the three oblasti. The response rate for generating interviews at the original households was 15 per cent, 41 per cent when the households on either side are included and 68 per cent when the two households on either side are included. Although this survey of course is not representative of Moscow as a whole, it nevertheless unravels the multifarious kinds of labour being used in contrasting oblasti in this city and how work cultures and the nature of individual labour practices vary socio-spatially. Table 1 outlines the socio-demographic profile of the participants in each of the three oblasti. This reveals that in the affluent oblast, the residents have lived there for much shorter periods than in the deprived and mixed oblasti, the number of people in households is greater and there are more couple households, the average age is lower and the total gross household income is significantly higher. Similarly, although deprived and mixed oblasti are similar in terms of the number of people in households, the gender composition of households, age profile of respondents and the work history of households, those in the mixed oblast have lived there longer than in the deprived oblast and the total gross household income in the mixed area reflects the polarised nature of household income levels, whilst the deprived oblast reflects the lower overall income levels. It is important to note, 
Table 1. Socio-demographic profile of participants in Moscow survey: by locality-type

\begin{tabular}{|c|c|c|c|c|}
\hline$\%$ of respondents & $\begin{array}{c}\text { Affluent oblast- } \\
\text { Krylatskoe }\end{array}$ & $\begin{array}{c}\text { Deprived oblast - } \\
\text { South-East }\end{array}$ & $\begin{array}{c}\text { Mixed oblast - } \\
\text { Leshkovo }\end{array}$ & All \\
\hline & $\mathrm{n}=125$ & $\mathrm{n}=100$ & $\mathrm{n}=88$ & $\mathrm{n}=313$ \\
\hline \multicolumn{5}{|l|}{ Number of years lived in area: } \\
\hline $0-5$ & 7 & 1 & 3 & 4 \\
\hline $6-10$ & 17 & 3 & 5 & 9 \\
\hline $11-15$ & 35 & 7 & 7 & 18 \\
\hline $16-20$ & 26 & 3 & 8 & 13 \\
\hline $21-25$ & 7 & 6 & 3 & 5 \\
\hline $26-30$ & 0 & 10 & 6 & 5 \\
\hline $31-35$ & 4 & 43 & 2 & 16 \\
\hline $36+$ & 4 & 27 & 66 & 30 \\
\hline \multicolumn{5}{|l|}{ Number of people in household: } \\
\hline 1 people & 28 & 47 & 48 & 40 \\
\hline 2 people & 24 & 11 & 36 & 23 \\
\hline 3 people & 28 & 21 & 10 & 21 \\
\hline 4 people & 10 & 9 & 3 & 8 \\
\hline 5 people & 9 & 10 & 1 & 7 \\
\hline $6+$ people & 1 & 2 & 2 & 1 \\
\hline \multicolumn{5}{|c|}{ Adult gender composition of household: } \\
\hline Female only & 28 & 52 & 51 & 42 \\
\hline Male only & 7 & 6 & 8 & 7 \\
\hline Male and female & 65 & 42 & 41 & 51 \\
\hline \multicolumn{5}{|l|}{ Age of respondent: } \\
\hline $16-25$ & 14 & 4 & 2 & 8 \\
\hline $26-35$ & 10 & 5 & 3 & 7 \\
\hline $36-45$ & 14 & 9 & 6 & 10 \\
\hline $46-55$ & 10 & 9 & 10 & 10 \\
\hline $56-65$ & 4 & 12 & 18 & 11 \\
\hline$>65$ & 48 & 61 & 61 & 54 \\
\hline \multicolumn{5}{|l|}{ Work history of household: } \\
\hline Continuous employment of all & 14 & 22 & 23 & 19 \\
\hline Mostly all employed & 21 & 20 & 14 & 19 \\
\hline Mostly all unemployed & 11 & 7 & 6 & 8 \\
\hline Continuously unemployed & 12 & 7 & 3 & 8 \\
\hline Pension since post-socialist time & 42 & 44 & 54 & 46 \\
\hline \multicolumn{5}{|l|}{ Total gross household income $(R)$ : } \\
\hline$<3000$ & 5 & 20 & 2 & 8 \\
\hline $3001-7000$ & 18 & 28 & 38 & 27 \\
\hline $7001-11000$ & 10 & 26 & 9 & 14 \\
\hline $11001-15000$ & 9 & 6 & 10 & 8 \\
\hline $15001-19000$ & 12 & 10 & 11 & 11 \\
\hline$>19,000$ & 46 & 10 & 30 & 32 \\
\hline
\end{tabular}

3.7 To evaluate the plethora of labour practices used, previous studies indicate that respondents find it difficult to recall when various kinds of labour were used or supplied when open-ended relatively unstructured interviews are employed (e.g.,Leonard, 1994; Pahl, 1984; Williams, 2004). At the outset, therefore, the decision was taken to use structured interviews. Besides gathering background data on gross household income, the employment status of household members, their employment histories, ages and gender, firstly, respondents were asked about the forms of work they primarily and secondarily rely on to secure a livelihood, secondly, the sources of labour the household last used to complete 25 common domestic services (see Table 2) so that comparative data was available across oblasti on the different labour practices used for the same set of tasks, thirdly, whether they had undertaken any of these 25 tasks for others during the past year and if so what labour practice had been used. Fourthly, open-ended questions were then asked about any other work conducted using each of the eight labour practices and fifth and finally, and using five-point likert scaling, attitudinal questions concerning their ability to draw upon help from others and their views of the economy, politics, everyday life and their future prospects.

Table 2. 25 common domestic services surveyed in contemporary Moscow

Task

Home maintenance \& improvement

Indoor painting

Wallpapering

Replace broken window

Maintain appliances

Double glazing

Plumbing

Improve kitchen

Improve bathroom

Improve flooring

Domestic work

Routine housework

Clean inside windows

Shopping

Wash/iron clothes
Cooking

Wash dishes

Hairdressing

Book-keeping

Making/repairing goods

Make/Repair clothes

Make/repair curtains

Make/repair tools

Make/repair fumiture

Caring

Daytime childcare

Evening childcare

Tutoring

Tend sick

\section{Mapping the social organisation of labour in moscow}

4.1 Table 3 reports the labour practices used to conduct a set of 25 common tasks across different oblasti and household income levels. The reason for using a set of 25 common everyday tasks was so as to allow comparative data to be gathered on the labour practices used for the same set of tasks. The finding is that participation in the formal paid labour market is not extensive in Moscow. Of course, this has to be seen in 
the context of the relatively large number of retired people interviewed. Nevertheless, only just one-third (37 per cent) of respondents had engaged in formal paid employment over the past year even though 46 per cent of participants were of working wage, meaning that one-fifth of working-age respondents has not engaged in formal paid employment during the past year. Relative to self-provisioning (which everybody had undertaken over the past year), unpaid one-to-one labour (which 63 per cent had conducted) and paid favours (65 per cent), participation in the formal labour market is thus confined to small pockets of the Muscovite population.

Table 3. Participation rates in labour practices: by locality and gross household income Monetized

\begin{tabular}{|c|c|c|c|c|c|c|c|c|}
\hline & \multicolumn{4}{|c|}{ Monetized } & \multicolumn{4}{|c|}{ Non-monetized } \\
\hline & $\begin{array}{l}\text { Formal } \\
\text { job }\end{array}$ & $\begin{array}{l}\text { Informal } \\
\text { employment }\end{array}$ & $\begin{array}{l}\text { Paid } \\
\text { favours }\end{array}$ & $\begin{array}{l}\text { Paid } \\
\text { family } \\
\text { labour }\end{array}$ & $\begin{array}{l}\text { Formal } \\
\text { unpaid } \\
\text { labour }\end{array}$ & $\begin{array}{l}\text { Off-the-radar } \\
\text { unpaid labour in } \\
\text { groups }\end{array}$ & $\begin{array}{l}\text { One-to-one } \\
\text { unpaid labour }\end{array}$ & $\begin{array}{l}\text { Self- } \\
\text { provisioning }\end{array}$ \\
\hline $\begin{array}{l}\text { All areas } \\
\text { Locality-type: }\end{array}$ & 37 & 24 & 65 & 5 & 31 & 1 & 63 & 100 \\
\hline Deprived & 25 & 20 & 48 & 1 & 20 & 2 & 72 & 100 \\
\hline Mixed & 30 & 23 & 68 & 4 & 28 & 1 & 70 & 100 \\
\hline Affluent & 54 & 30 & 75 & 7 & 39 & 0 & 52 & 100 \\
\hline Gross Househ & hold inco & & & & & & & \\
\hline $\begin{array}{l}\text { Lowest } \\
\text { quartile }\end{array}$ & 23 & 20 & 41 & 1 & 18 & 2 & 72 & 100 \\
\hline $\begin{array}{l}\text { Lower } \\
\text { quartile }\end{array}$ & 31 & 22 & 63 & 3 & 33 & 3 & 65 & 100 \\
\hline $\begin{array}{l}\text { Upper } \\
\text { quartile }\end{array}$ & 41 & 28 & 74 & 5 & 35 & 1 & 60 & 100 \\
\hline
\end{tabular}

4.2 Nevertheless, participation rates vary socio-spatially. Engagement in formal paid employment ranges from 25 per cent in the deprived district through 40 per cent in the mixed district to 54 per cent in the affluent district, with greater proportions of the working-age population not engaging in formal employment in the deprived than affluent district (36 per cent compared with 7 per cent). Similarly, participation in formal employment was just 25 per cent amongst those adults living in the lowest-income quartile of households, but 31 per cent in the lower middle-income quartile, 41 per cent in the upper middle-income quartile and 57 per cent in the highest-income quartile. However, it is not just engagement in formal paid employment which varies socio-spatially. Participation rates in all eight labour practices (with the exception of unpaid one-to-one labour and off-the-radar unpaid labour in organisations) are higher in the affluent compared with deprived populations. In Moscow, therefore, there appear to be relatively 'work busy' populations engaged in a wide range of labour practices, especially market-oriented and monetized practices, and relatively 'work deprived' populations engaged in a narrower range of practices.

4.3 The socio-spatial variations in the penetration of capitalism and the differences in the organization of labour can also be seen when one examines the practices that households in different districts use to getby in everyday life. Evaluating the source of labour last used to conduct 25 common domestic service tasks, as Table 4 reveals, the finding is that there is a relatively shallow permeation of daily life by formal labour. Formal labour, for instance, was last used in just 7 per cent of instances to get these common domestic tasks completed. Indeed, only 26 per cent of domestic tasks even involved paid labour; the remaining three-quarters were last conducted by unpaid labour, with some two-thirds (67 per cent) conducted on a self-provisioning basis.

Table 4. Labour practices used by households to conduct everyday domestic services: by locality and gross household income

\begin{tabular}{|c|c|c|c|c|c|c|c|c|c|c|}
\hline & $\begin{array}{l}\text { Formal } \\
\text { job }\end{array}$ & $\begin{array}{l}\text { Informal } \\
\text { employment }\end{array}$ & $\begin{array}{l}\text { Paid } \\
\text { favours }\end{array}$ & $\begin{array}{l}\text { Paid } \\
\text { family } \\
\text { labour }\end{array}$ & $\begin{array}{l}\text { All } \\
\text { paid }\end{array}$ & $\begin{array}{l}\text { Formal } \\
\text { unpaid } \\
\text { labour }\end{array}$ & $\begin{array}{l}\text { Off-the-radar } \\
\text { unpaid } \\
\text { labour in } \\
\text { groups }\end{array}$ & $\begin{array}{l}\text { One-to- } \\
\text { one } \\
\text { unpaid } \\
\text { labour }\end{array}$ & $\begin{array}{l}\text { Self- } \\
\text { provisioning }\end{array}$ & $\begin{array}{l}\text { All } \\
\text { unpaid }\end{array}$ \\
\hline $\begin{array}{l}\text { All areas } \\
\text { Locality-type. }\end{array}$ & 7 & 12 & 7 & $<1$ & 26 & $<1$ & $<1$ & 7 & 67 & 74 \\
\hline Deprived & 4 & 7 & 4 & $<1$ & 15 & 1 & $<1$ & 7 & 78 & 85 \\
\hline Mixed & 4 & 12 & 8 & $<1$ & 24 & $<1$ & $<1$ & 9 & 67 & 76 \\
\hline Affluent & 10 & 13 & 9 & 1 & 32 & $<1$ & $<1$ & 6 & 62 & 68 \\
\hline \multicolumn{11}{|c|}{ Gross household income: } \\
\hline $\begin{array}{l}\text { Lowest } \\
\text { quartile }\end{array}$ & 2 & 4 & 4 & $<1$ & 10 & $<1$ & $<1$ & 11 & 79 & 90 \\
\hline $\begin{array}{l}\text { Lower } \\
\text { quartile }\end{array}$ & 4 & 9 & 6 & $<1$ & 19 & $<1$ & $<1$ & 7 & 74 & 81 \\
\hline $\begin{array}{l}\text { Upper } \\
\text { quartile }\end{array}$ & 8 & 14 & 8 & $<1$ & 30 & $<1$ & $<1$ & 6 & 64 & 70 \\
\hline $\begin{array}{l}\text { Highest } \\
\text { quartile }\end{array}$ & 14 & 21 & 10 & 2 & 45 & $<1$ & $<1$ & 4 & 51 & 55 \\
\hline
\end{tabular}

Source: Moscow labour practices survey 2005-06

4.4 Nevertheless, there are differences across populations in both the permeation of formal labour and their overarching work cultures. As Table 4 reveals, people living in the affluent district more commonly use formal labour in particular, and paid labour in general, than those in the deprived district. The vast majority of outsourcing of domestic tasks amongst the Moscow households surveyed, however, is to paid informal labour rather than to the formal economy. The degree to which households externalize to the monetized and formal sphere is not the only difference in work cultures across populations. Other labour practices are also used to differing extents and in varying combinations. Those living in deprived districts more heavily rely upon self-provisioning and unpaid one-to-one labour. So too do those households in the lowest- and lower middle-income quartile compared with more affluent households, who rely more on paid favours, informal employment and formal labour.

4.5 The overarching finding, however, is not simply that relatively affluent populations are more likely to engage in formal and paid labour practices whilst deprived populations are more likely to engage informal and unpaid labour practices. This is only a partial representation of the socio-spatial variations in the organisation of labour. Rather, there seems to exist a spectrum ranging from relatively affluent 'work busy' 
populations who engage in a multitude of labour practices (as shown by their higher participation rates in most sources of labour) to relatively disadvantaged 'work deprived' populations who conduct a much narrower range of practices.

4.6 Socio-spatial variations prevail not just in the penetration of formalization and the range of and type of labour practices conducted, but also in the nature of each labour practice used in terms of the work relations and motives involved. To understand these socio-spatial variations in individual labour practices each is now evaluated in turn.

\section{Self-provisioning labour}

4.7 Self-provisioning is unpaid work undertaken for oneself or other members of one's household, and its nature markedly varies across the deprived and affluent populations surveyed in Moscow. For the lowestincome quartile of households, self-provisioning in some 90 per cent of cases was a coping tactic conducted out of economic necessity in the absence of other options, and usually involved routine, mundane and repetitive tasks (e.g., routine housework) whilst the highest-income quartile of households outsource greater portions of this routine work and then use a portion of the time freed to conduct a wider array of more creative and rewarding self-servicing (e.g., home improvement activities, productive work on their dacha) which in 75 per cent of cases was conducted out of choice in preference to other options (e.g., outsourcing to the formal economy or paid informal labour). Self-provisioning, therefore, qualitatively differs in affluent compared with disadvantaged populations.

4.8 Moreover, it is often intimately entwined with other forms of labour, either used alongside other practices (e.g., formal labour, community exchange) to get tasks done, or in conjunction with other practices for different stages in the production process. Given the commonly expressed desire for equivalent reciprocity between partners in couple households, with one partner taking responsibility for doing one task and their partner responsibility for another, or one doing the housework because the other earned a wage, self-provisioning was commonly embedded in work relations and motives similar to one-toone unpaid labour and paid favours.

\section{Reimbursed family labour}

4.9 Sometimes family members are paid by other family members within their household for conducting tasks. In this Moscow survey, this only occurs in inter- rather than intra-generational transactions (e.g., from a parent to a child, not between two parents, although this blurs in the case of divorcees). This labour practice whereby parents pay children for tasks (e.g., housework duties) is also more prevalent in relatively affluent populations. In more deprived populations, gifts rather than money tend to be involved. Indeed, when gifts are given to family members within the same household for tasks, the divide between selfprovisioning and paid family labour becomes blurred, and this is even more the case when in-kind labour or equivalent reciprocity is involved.

\section{One-to-one unpaid labour}

4.10 Reviewing unpaid help provided either on a one-way or reciprocal basis by or for kin living outside the household, friends, neighbours or acquaintances, just under 72 per cent of respondents in the deprived populations and 52 per cent in the affluent populations participated in this practice over the previous year. Much is for kin living outside the household. When non-kin are involved (e.g., neighbours, friends), token payments, gifts or in-kind labour are usually preferred and used whenever feasible. The use of wholly unpaid labour is greater in deprived populations, therefore, only because they more heavily rely on kin, lack the purchasing power to use money or gifts, and/or the physical well-being to reciprocate with in-kind labour, so engage by default in unpaid one-to-one exchange out of necessity in the absence of alternatives. Moreover, while affluent populations engage in this practice more to expand their social networks and consolidate relationships and in two-thirds of cases choose to use this practice, deprived populations rely more on narrower social networks of kin and use this practice as a coping tactic to meet material needs and are twice as likely to do so out of necessity and in the absence of alternatives.

\section{Reimbursed favours}

4.11 Reimbursed favours involve the provision of one-to-one help to either kin living outside the household, friends, neighbours or acquaintances where monetary payment is exchanged. Profit, nevertheless, is not always the primary or sole intention of the customer or the supplier. Reimbursed favours exist on a continuum ranging from those conducted for distant social relations or anonymous customers more for profit-oriented reasons to those undertaken for closer social relations where the profit-motive is largely absent and the rationales involve redistribution and consolidating social relationships, with many combinations in between. In relatively affluent populations, this survey finds that reimbursed favours were more orientated towards the profit-motivated end of the spectrum and therefore closer to informal more orientated towards the profit-motivated end of the spectrum and therefore closer to informal
employment in terms of the work relations, values and motives involved, whilst in the deprived populations such favours were usually closer to the redistributive end of the continuum and therefore unpaid mutual aid in terms of the social relations, values and motives within which such endeavour was embedded.

4.12 Customers, for example, often pay closer social relations for tasks in order to redistribute money to them in a benevolent way but in a manner that avoids any connotation of 'charity', or so as to avoid favours owed accumulating in situations where it might not be feasible or possible to return them. Paying for favours thus oils the wheels for reciprocity in situations where it might not otherwise feasibly occur, such as when one is physically unable to return favours, or too time pressured to be able to offer in-kind labour in return. As Zelizer (2005) asserts, the introduction of money does not depersonalize social interactions and turn them into market transactions. People create distinctions between different types of reimbursement and the social relations to which they give rise. Not all reimbursed favours, however, involve monetary payments. Sometimes gifts are involved. Indeed, examining the proportion of favours that involve reimbursement in the form of money or gifts, the finding is that half involved payment, although this reached three-quarters of one-to-one favours in relatively affluent populations. In consequence, payment appears to be common whenever favours are exchanged.

\section{Informal employment}

4.13 Informal employment refers to paid activities not registered by, or hidden from, the state for tax, social security and/or labour law purposes (Williams, 2009). A continuum of types exist ranging from at one end informal paid labour akin to formal paid labour in terms of the work relations and motives involved to at the other end, those engaged in paid informal practices more akin to unpaid mutual aid, as discussed above. Examining here the varieties along the spectrum towards formal paid labour, there is firstly different varieties of wholly undeclared labour and secondly types of under-declared formal employment. Wholly undeclared labour can be either waged work or informal self-employment. In Moscow, this wholly undeclared labour can be either waged work or informal self-employment. In Moscow, this wholly paid informal self-employment or waged work, while relatively deprived populations conduct either low-paid 'sweatshop-like' waged labour or low-paid informal self-employment under precarious conditions. Contrary to the arguments of De Soto (1989) and Maloney (2004) who argue that informal employment is a chosen alternative, this is here found to be the case only amongst the relatively affluent. Most engage in such labour due to a lack of choice rather than as a matter of choice. From street-traders selling flowers or vegetables grown on their dacha, through cigarette sellers in railway stations to skilled craftspeople providing their self-employed services to households and businesses, such informal employment was providing their self-employed services to households and businesses, such informal employment was
widely recited to be a necessity due to either the absence of alternatives or the pay that they received from widely recited to be a necessity due to either the absence of alternatives or the pay that they received
their formal labour being insufficient. Under-declared work, meanwhile, and as will now be revealed, is similarly not largely conducted by employees out of choice even though it is extensive. 
4.14 In Moscow, only 37 per cent of the surveyed population had participated in the year prior to the survey in paid formal labour registered by the state for tax, social security and/or labour law purposes and 22 per cent in formal labour in the private sector, although participation rates are higher in affluent than deprived populations (see Table 4). A popular belief has been that a job is either formal or informal, but cannot be both. However, this survey reveals that a large proportion of formal employees in formal jobs in Moscow are paid an undeclared ('envelope') wage in addition to their official declared wage, as is also commonly the case elsewhere in Central and Eastern Europe (Williams, 2009). In Moscow, this additional undeclared wage is usually not for over-time. It is a component of their core wage. Some 76 per cent of full-time formal wage is usually not for over-time. It is a component of their core wage. Some 76 per cent of full-time formal
employees and 61 per cent of part-time employees receive such a wage which amounts on average to 40 per cent of their total wage packet. Few receiving this envelope wage, however, see this as beneficial because it reduces their pension and unemployment entitlements as well as their ability to access credit with many unable to secure a mortgage or loans due to having no official record of their 'real' wage. Nor is it a chosen practice. Nearly all employees receiving it asserted that it was imposed on them by their formal employer. This labour practice therefore reveals that informal employment is not separate from the formal economy but part and parcel of the Moscow economy and inseparable from it. Indeed, the vast majority of formal employees in Moscow are in jobs that are very much located at the formal/informal borderline.

\section{Formal unpaid labour}

4.15 In Moscow, people often work unpaid for a trial period when offered a formal job in the private (or public) sector. Indeed, 30 per cent of those surveyed who had started a new formal job over the past 12 months had been asked to do so by their potential future employer. This was especially the case amongst younger age groups who were seeking a job. A significant minority at the end of their trial period had not been employed. Respondents often asserted this to be a deliberate employer strategy to get 'free labour'. Further detailed research is required of whether this is indeed a common employer practice, or simply a result of potential employees being inappropriate. No similar tendencies were identified in the public sector. Some 20 per cent of formal employees, moreover, asserted that their weekly or monthly wage had not been paid to them at some point over the past year. On the whole, it was the undeclared component of their wage that had not been paid, although 8 per cent of formal employees asserted that the declared wage had not. Indeed, it is for this reason that benefits and pensions are valued highly as income streams. Unlike the income from formal labour, they are seen as reliable sources of income.

4.16 The largest realm of unpaid formal labour is in community-based groups, conducted by a quarter of respondents, with participation rates being greater in affluent than deprived communities (see Table 3). respondents, with participation rates being greater in affluent than deprived communities (see Table 3).
Such activity, however, is not used to deliver material aid. As Table 4 displays, less than 1 per cent of the common domestic services were provided through community-based groups. If such unpaid engagement in formal community-based organizations is not providing material support to households, then what is it doing? In 90 per cent of cases, the primary purpose of engagement for respondents was to receive social or emotional support. Just 10 per cent asserted that the primary purpose was to provide material aid to others. This raises a crucial issue. If the intention is to develop civil society in order to meet material needs not met by other fields of provision, such as the private or public sectors, then developing participation in community-based groups is wholly inappropriate in Moscow. Instead, the nurturing of other participation in community-based groups is
labour practices will need to be considered.

\section{Off-the radar unpaid labour in groups}

4.17 Sometimes those engaged in unpaid labour in community-based groups might do so illegitimately or informally, such as when caring for children in a community-based group but without the required licenses to act as child carer, or when operating a sporting group, community fund-raising or music event without the necessary licenses. On the whole, few instances of such a labour practice were identified. However, further research could be usefully undertaken focused on this issue, especially around the paid/unpaid interface, where respondents expressed some confusion about whether the various current legal interface, where respondents expressed some confusion about whether the various current legal
responsibilities only apply, such as when caring for others children, if paid and that if unpaid, they were not applicable.

\section{Conclusions}

5.1 To move beyond the conventional erroneous depiction of formal and informal labour as discrete forms of labour and hostile forms composed of different economic relations, values and motives, this paper has adopted a total social organization of labour (TSOL) approach in order to resolve the problem of representing the multifarious labour practices in societies. To do this, labour practices have been situated representing the multifarious labour practices in societies. To do this, labour practices have been situated
along a spectrum from relatively formal to more informal labour practices cross-cut with a further spectrum from non-monetized, through gift exchange and in-kind reciprocal labour, to monetized labour.

5.2 This conceptual lens has been then applied to evaluating the organization of labour in Moscow. One finding is the relatively shallow penetration of the formal economy although the depth to which it has permeated everyday life varies socio-spatially. Another finding is that work cultures also vary. Those living in affluent populations adopt more formal and monetized work cultures whilst those in lower-income in affluent populations adopt more formal and monetized work cultures whilst those in lower-income
populations are more reliant on community exchanges between closer social relations, both of the monetized and non-monetized variety, as well as self-provisioning. The character of each labour practice also varies socio-spatially. On the whole, affluent populations engage in a greater range of labour practices, and do so out of choice whilst deprived populations employ a narrower range of practices which they engage in more out of necessity in the absence of alternatives. The outcome is that uneven development in Moscow is not characterized by affluent populations being more formalized and monetized. Rather uneven development in Moscow is characterized by affluent populations that are 'work busy' across the spectrum engaging in a wide array of labour practices and doing so more commonly out of choice, whilst deprived populations are more 'work deprived' engaging in a narrower range of labour practices which they do more commonly out of necessity.

5.3 Now required are further studies using the TSOL approach so as to understand whether the findings are similar in other societal contexts both within the transition economies as well as western nations and the global south. If this paper encourages such research to be conducted in order to facilitate a re-reading of the organization of labour in contemporary societies, then it will have achieved its objective.

\section{References}

ACKER, J. (2006) Class Questions: Feminist Answers, Lamham, MD: Rowman and Littlefield.

BOEKE, J.H. (1942) Economies and economic policy in dual societies, Haarlem: Tjeenk Willnik.

BRADLEY, H. (2007) Gender, Cambridge: Polity.

BROOKE, C. (2006) Moscow: a cultural history, Oxford: Oxford University Press.

BURAWOY, M. and VERDERY, K. (1999) (eds.) Uncertain Transition: ethnographies of change in the postsocialist world, Oxford: Rowman and Littlefield.

BUTLER, J. (1990) Gender Trouble: Feminism and the Subversion of Identity, London: Routledge.

CALDWELL, M. L. (2004) Not by bread alone: social support in the New Russia, London: University of 
California Press.

CASTELLS, M. \& PORTES, A. (1989). 'World underneath: the origins, dynamics and effects of the informal economy', in A. Portes, M. Castells \& L.A. Benton (eds.), The Informal Economy: studies in advanced and less developing countries, pp.1-19, Baltimore: John Hopkins University Press.

CHAKRABARTY, D. (2000) Provincializing Europe: postcolonial thought and historical difference, Princeton: Princeton University Press.

CHARMES, J. (2009) 'Concepts, measurement and trends', in J.P. Jütting and J.R. Laiglesia (eds.), Is Informal Normal? Towards more and better jobs in developing countries, Paris: OECD.

CHEN, M. (2006) 'Rethinking the informal economy: linkages with the formal economy and the formal regulatory environment', in B. Guha-Khasnobis, R. Kanbur and E. Ostrom (eds.) Linking the Formal and Informal Economy: concepts and policies, pp.75-92, Oxford: Oxford University Press.

[doi:10.1093/0199204764.003.0005]

CHOWDHURY, S.A. (2007) Everyday economic practices: the 'hidden transcripts' of Egyptian voices, London: Routledge. [doi:10.4324/9780203943830]

CLARKE, S. (2002) Making ends meet in contemporary Russia: secondary employment, subsidiary agriculture and social networks, Cheltenham: Edward Elgar.

COMMUNITY ECONOMIES COLLECTIVE (2001) 'Imagining and enacting noncapitalist futures', Socialist Review, Vol. 28, pp. 93-135.

CROMPTON, R. (2006) Employment and the Family, Cambridge: Cambridge University Press. [doi:10.1017/CBO9780511488962]

DAVIS, M. (2006) Planet of Slums, London: Verso.

DE SOTO, H. (2001) The Mystery of Capital: why capitalism triumphs in the West and fails everywhere else, London: Black Swan.

DE SOTO, H. (1989) The Other Path, London: Harper and Row.

DERRIDA, J. (1967) Of Grammatology, Baltimore: John Hopkins University Press.

ELKIN, T. and D. McLAREN (1991) Reviving the City: towards sustainable urban development, London: Friends of the Earth.

ESCOBAR, A. (1995) Encountering Development: the making and unmaking of the third world, Princeton: Princeton University Press.

ESCOBAR, A. (2001) 'Culture sits in places: reflections of globalism and subaltern strategies of localization', Political Geography, Vol. 20, pp. 139-74; [doi:10.1016/S0962-6298(00)00064-0]

EUROPEAN COMMISSION (2008) Stepping up the fight against undeclared work, Brussels: European Commission.

FEIGE, E.L. and URBAN, I. (2008) 'Measuring underground (unobserved, non-observed, unrecorded) economies in transition countries: can we trust GDP?', Journal of Comparative Economics, Vol. 36, no. 2 , pp. 287-306. [doi:10.1016/j.jce.2008.02.003]

FERNANDEZ-KELLY, P. (2006) 'Introduction', in P. Fernandez-Kelly and J. Shefner (eds.) Out of the Shadows: political action and the informal economy in Latin America, pp.1-19, Pennsylvania: Penn State Press.

FOUCAULT, M. (1981) The order of discourse. Inaugural lecture at the College de France, given 2 December 1970', in R. Young (ed.) Untyping the text: a poststructuralist reader, London: Routledge and Kegan Paul.

GEERTZ, C. (1963) Old Societies and New States: the quest for modernity in Asia and Africa, Glencoe, IL: Free Press.

GIBSON-GRAHAM, J.K. (1996) The End of Capitalism (as we knew it)?: a feminist critique of political economy, Oxford: Blackwell.

GIBSON-GRAHAM, J.K. (2006) A Post-Capitalist Politics, Minneapolis: University of Minnesota Press.

GIBSON-GRAHAM, J.K. (2008) 'Diverse economies: performative practices for "other worlds"', Progress in Human Geography, Vol. 32, no. 5, pp. 613-32. [doi:10.1177/0309132508090821]

GLUCKSMANN, M. (1995) 'Why work? gender and the total social organization of labor', Gender, Work and Organization, Vol. 2, no. 2, pp. 63-75. [doi:10.1111/j.1468-0432.1995.tb00028.x]

GLUCKSMANN, M. (2000) Cottons and Casuals: the gendered organisation of labour in time and space, Durham: Sociology press.

GLUCKSMANN, M. (2005) 'Shifting boundaries and interconnections: extending the "total social organization of labor"', The Sociological Review, Vol. 53, No. 2, pp.19-36.

GLUCKSMANN, M. (2009) 'Formations, connections and divisions of labour', Sociology, Vol. 43, no. 5, pp. 878-95. [doi:10.1177/0038038509340727]

GUPTA, A, (1998) Postcolonial development: agriculture in the making of modern India, Durham, NC: Duke University Press.

ILO (2002) Decent work and the informal economy, Geneva: International Labour Office.

JUTTING, J.P. and LAIGLESIA, J.R. (2009) 'Employment, poverty reduction and development: what's new?', in J.P. Jütting and J.R. Laiglesia (eds.) Is Informal Normal? Towards more and better jobs in developing countries, Paris: OECD.

KIM, B-Y (2002) 'The participation of Russian households in the informal economy: evidence from the VTsIOM survey', Economics of Transition, Vol. 10, pp. 689-717. [doi:10.1111/1468-0351.t01-1-00130]

KITCHIN, R. and TATE, N. (2001) Conducting research in human geography: theory, practice and methodology, London: Prentice Hall.

LATOUCHE, S. (1993) In the wake of affluent society: an exploration of post-development, London: Zed.

LEDENEVA, A.V. (1998) Russia's economy of favours: blat, networking and informal exchange, Cambridge: Cambridge University Press.

LEDENEVA, A.V. (2006) How Russia really works: the informal practices that shaped post-Soviet politics 
and business, London: Cornell University Press.

LEE, R. (2006) 'The ordinary economy: tangled up in values and geography', Transactions of the Institute of British Geographers, Vol. 31, No. 4, pp. 413-32. [doi:10.1111/j.1475-5661.2006.00223.x]

LEONARD, M. (1994) Informal Economic Activity in Belfast, Aldershot: Avebury.

LEONARD, M. (1998) Invisible work, invisible workers: the informal economy in Europe and the US, London: Macmillan.

LEWIS, A. (1959) The theory of economic growth, London: Allen and Unwin.

LEYSHON, A., LEE, R. \& WILLIAMS, C.C. (2003) (eds.) Alternative Economic Spaces, London: Sage.

LOW, N., BUTT, S., ELLIS PAINE, A. and DAVIS SMITH, J. (2008) Helping out: a national survey of volunteering and charitable giving, London: Office of the Third Sector.

LYON, D. AND GLUCKSMANN, M. (2008) 'Comparative configurations of care work across Europe', Sociology, Vol. 42, no. 1, pp. 101-18. [doi:10.1177/0038038507084827]

MACDONALD, R. (1994) 'Fiddly jobs, undeclared working and the something for nothing society', Work, Employment and Society, Vol. 8, No. 4, pp. 507-30.

MALONEY, W.F. (2004) 'Informality revisited', World Development, Vol. 32, no. 7, pp. 1159-78.

[doi:10.1016/j.worlddev.2004.01.008]

MASSEY, D. (2005) For Space, London: Sage.

MCDOWELL, L. (2005) Hard Labour: the forgotten voices of Latvian migrant volunteer workers, London: UCL Press.

PAHL, R.E. (1984) Divisions of Labor, Oxford: Blackwell.

PAVLOVSKAYA, M. (2004) 'Other transitions: multiple economies of Moscow households in the 1990s', Annals of the Association of American Geographers, Vol. 94, pp. 329-51. [doi:10.1111/j.14678306.2004.09402011.x

PETTINGER, L., PARRY, J., TAYLOR, R.F. AND GLUCKSMANN, M. (2005) A New Sociology of Work? Oxford: Blackwell.

POLLARD, J., McEWAN, C., LAURIE, N. and STENNING, A. (2009) 'Economic geography under postcolonial scrutiny', Transactions of the Institute of British Geographers, Vol. 34, No. 2, pp. 137-42. [doi:10.1111/j.1475-5661.2009.00336.x]

RENOOY, P. (1990) The informal economy: meaning, measurement and social significance, Amsterdam: Netherlands Geographical Studies Association.

ROSE, R. (2005) Insiders and Outsiders: New Europe Barometer 2004, Glasgow: Studies in Public Policy 404, Centre for the Study of Public Policy, University of Strathclyde.

ROUND, J. and WILLIAMS, C.C. (2008) 'Everyday tactics and spaces of power: the role of informal economies in post-Soviet Ukraine', Social and Cultural Geography, Vol. 9, No. 2, pp. 171-85. [doi:10.1080/14649360701856110]

SAMERS, M. (2005) 'The myopia of "diverse economies", or a critique of the "informal economy"', Antipode, Vol. 37, No. 5, pp. 875-86. [doi:10.1111/j.0066-4812.2005.00537.x]

SHEVCHENKO, O. (2009) Crisis and the Everyday in post-socialist Moscow, Indianapolis: Indiana University Press.

SLACK, T. (2007) 'The contours and correlates of informal work in rural Pennsylvania', Rural Sociology, Vol. 72, No. 1, pp. 69-89. [doi:10.1526/003601107781147392]

SLACK, T. and JENSEN, L. (2010) 'Informal work in rural America' in E. Marcelli, C.C. Williams and P. Joassart (eds.) Informal Work in Developed Nations, pp. 171-191, London: Routledge.

SMITH A. (2010) 'Informal work in the diverse economies of "post-socialist" Europe', in E. Marcelli, C.C. Williams and P. Joassart (eds.) Informal Work in Developed Nations, pp. 47-65. London: Routledge.

SMITH, A. and STENNING, A. (2006) 'Beyond household economies: articulations and spaces of economic practice in postsocialism', Progress in Human Geography, Vol. 30, No. 1, pp. 1-14.

STRANGLEMAN, T. and WARREN, T. (2008) Work and Society: Sociological approaches, themes and methods, London: Routledge.

TAYLOR, R.F. (2004) 'Extending conceptual boundaries: work, voluntary work and employment', Work, Employment \& Society, Vol. 18, No. 1, pp. 29-49. [doi:10.1177/0950017004040761]

TOKMAN, V.E. (1989), 'Policies of heterogeneous informal sector in Latin America', World Development, Vol. 17, pp. 1067-76. [doi:10.1016/0305-750X(89)90169-1]

WALLACE, C. and HAERPFER, C. (2002) 'Patterns of participation in the informal economy in EastCentral Europe', in R. Neef and M. Stanuclescu (eds.), The Social Impact of Informal Economies in Eastern Europe, pp. 28-47, Aldershot: Ashgate.

WALLACE, C. and LATCHEVA, R. (2006) 'Economic transformation outside the law: corruption, trust in public institutions and the informal economy in transition countries of Central and Eastern Europe', EuropeAsia Studies, Vol. 58, No. 1, pp. 81-102. [doi:10.1080/09668130500401707]

WILLIAMS, C.C. (2004) 'The myth of marketization: an evaluation of the persistence of non-market activities in advanced economies', International Sociology, Vol. 19, No. 4, pp. 437- 49. [doi:10.1177/0268580904047366]

WILLIAMS, C.C. (2005) A Commodified World? mapping the limits of capitalism, London: Zed.

WILLIAMS, C.C. (2006) The Hidden Enterprise Culture: entrepreneurship in the underground economy, Cheltenham: Edward Elgar.

WILLIAMS, C.C. (2009) 'Formal and informal employment in Europe: beyond dualistic representations', European Urban and Regional Studies, Vol. 16, No. 2, pp. 147-59. [doi:10.1177/0969776408101686]

WILLIAMS, C.C. (2010) 'Geographical variations in informal work in contemporary England', in E. Marcelli, C.C. Williams and P. Joassart (eds.) Informal Work in Developed Nations, pp. 97-113, London: Routledge.

WILLIAMS, C.C. and ROUND, J. (2007) 'Beyond negative depictions of informal employment: some lessons from Moscow', Urban Studies, Vol. 44, no. 12, pp. 321-38. [doi:10.1080/00420980701540945] 
WILLIAMS, J.C. and ZELIZER, V.A. (2005) To commodify or not to commodify: that is not the question', in M. Ertman and J.C. Williams (eds.) Rethinking Commodification: cases and readings in law and culture, pp. 362-82, New York: New York University Press.

WOOLFSON, C. (2007) 'Pushing the envelope: the "informalization" of labour in post-communist new EU member states', Work, Employment and Society, Vol. 21, No. 3, pp. 551-64.

[doi:10.1177/0950017007080016]

ZELIZER, V.A. (2005) The Purchase of Intimacy, Princeton: Princeton University Press. 